by Roberto Greco ${ }^{1}$, Sylke Hlawatsch ${ }^{2}$, Nicholls Bronte ${ }^{3}$

\title{
The International Earth Science Olympiad (IESO): A way to raise public awareness of geoscience, particularly amongst younger people and enhance the quality of geoscience education internationally
}

\author{
${ }^{1}$ Department of Geosciences applied to teaching, Institute of Geosciences - Unicamp CP. 6152 - 13083-970 Campinas - SP Brasil \\ E-mail: greco@ige.unicamp.br \\ ${ }^{2}$ Richard-Hallmann-Gemeinschaftsschule mit gymnasialer Oberstufe der Gemeinde Trappenkamp, Gablonzerstr. 42, D-24610 Trappenkamp, \\ Germany.E-mail: kontakt@sylke-hlawatsch.de \\ 3 Australian Science and Mathematics School, Flinders University Bedford Park, South Australia, Australia. \\ E-mail: bronte.nicholls@asms.sa.edu.au
}

Since 1959 when the first International Math Olympiad for school students was held, other scientific Olympiads have developed, last but not least, the International Earth Science Olympiad-(IESO) in 2007.

This article summarizes the organisation of this event that to date has involved 39 countries and aims to involve more in the future. IESO is a competition for school students where the best students from all over the world test their knowledge and abilities in the subject. It is an amazing opportunity for brilliant students, with an interest in Earth science to get to know each other, share their passion and grow an international network. It highlights the importance of increasing the range of countries that participate in this competition and the role national selection processes can play to focus the attention of National Ministries of Education to give the appropriate time and space for Earth science in the school curricula. This in turn can lead to more school students continuing with post-school studies in the Earth sciences and take up careers in this field, following their passion for Earth science and thus contributing to their countries growth.

\section{Introduction}

The International Science Olympiads are separate competitions that are held annually, hosted by a different country each year. In general at each Science Olympiad (Table 1) groups of 4-6 students take part and are selected at national level by the National Olympics Committee. These Olympiads are for senior secondary school students except the IJSO which is devoted to junior secondary school students. The Olympiads have a set of common aims: to challenge the brightest students across the world; to promote interest in science careers; to compare national school systems, and give the opportunity for experts in education from different countries to share good practice.

The number of countries that took part at each Olympiad varies according to the history of the competition, and the attention that National Governments and societies give different subjects.

The idea to create an International Earth Science Olympiad originated from the International Geoscience Education Organization (IGEO) (http://www.geoscied.org/) because this was the last scientific subject without an international competition. IGEO is affiliated to and sponsored by the International Union of Geological Sciences (IUGS) and collaborates with the Commission on Geoscience Education, Training and Technology Transfer (COGE). Members from over 35 countries are represented in IGEO.

\section{What is IESO}

The International Earth Science Olympiad (IESO) is an annual Earth Science competition where school students from all over the world test their knowledge about geology (Fig.1G), hydrology (Fig.1B), meteorology (Fig.1D), climate and astronomy (Fig.1E) from an Earth Systems perspective.

Entry to the Olympiad is open to one team from each participating country, with each national delegation consisting of four participants and two mentors, but additional student guests, general guests and observers are allowed and welcomed. The participants must be secondary school students, not older than 18 years on July $1^{\text {st }}$ of the year of the Olympiad. The participants must not be university/college students. If they have already graduated before the competition, the organizer must be informed about the date of their graduation.

The activities of the IESO usually occur over 8-10 days. The mentors accompanying the students must be specialists in Earth science and/or Earth science education and capable of serving as members of the International Jury. The mentors must be able to speak the official language of the IESO, English, and thus translate the written examinations and related materials from English to the participants' native language, and be prepared to spend one or two 
Table.1: International Science Olympiad

\begin{tabular}{|c|c|c|c|c|c|}
\hline International Science Olympiad & $\begin{array}{l}\text { First host } \\
\text { country }\end{array}$ & $\begin{array}{c}\text { First } \\
\text { edition }\end{array}$ & $\begin{array}{l}\text { Host country } \\
\text { in } 2012\end{array}$ & $\begin{array}{l}\text { Number of parti- } \\
\text { cipants in } 2012\end{array}$ & $\begin{array}{l}\text { Host country } \\
\text { in } 2013\end{array}$ \\
\hline $\begin{array}{l}\text { International Mathematical Olympiad - IMO } \\
\text { http://www.imo-official.org/ }\end{array}$ & Romania & 1959 & Argentina & 100 & Colombia \\
\hline $\begin{array}{l}\text { International Phisics Olympiad - IphO } \\
\text { http://ipho.phy.ntnu.edu.tw/ }\end{array}$ & Poland & 1967 & Estonia & 80 & Denmark \\
\hline $\begin{array}{l}\text { International Chemistry Olympiad - IchO } \\
\text { http://www.icho.sk/ }\end{array}$ & Czechoslovakia & 1968 & USA & 79 & Russia \\
\hline $\begin{array}{l}\text { International Olympiad in Informatics - IOI } \\
\text { http://www.ioinformatics.org }\end{array}$ & Bulgaria & 1989 & Italy & 86 & Australia \\
\hline $\begin{array}{l}\text { International Biology Olympiad - IBO } \\
\text { http://www.ibo-info.org/ }\end{array}$ & Czechoslovakia & 1990 & Singapore & 59 & Switzerland \\
\hline $\begin{array}{l}\text { International Astronomy Olympiad - IAO } \\
\text { http://www.issp.ac.ru/iao/ }\end{array}$ & Russia & 1996 & South Korea & 16 & Lithuania \\
\hline $\begin{array}{l}\text { International Geography Olympiad - iGeO } \\
\text { http://www.geoolympiad.org/ }\end{array}$ & The Netherlands & 1996 & Germany & 32 & Japan \\
\hline $\begin{array}{l}\text { International Junior Science Olympiad } \\
\text { (under } 15 \text { years old) -IJSO http://www.ijso.ir/ }\end{array}$ & Indonesia & 2004 & Iran & 32 & India \\
\hline $\begin{array}{l}\text { International Olympiad on Astronomy and } \\
\text { Astrophysics IOAA. http://ioaa.info/ioaa2007/ }\end{array}$ & Thailand & 2007 & Brazil & 32 & Greece \\
\hline $\begin{array}{l}\text { International Earth Science Olympiad - IESO } \\
\text { http://www.ieso-info.org/ }\end{array}$ & South Korea & 2007 & Argentina & 19 & India \\
\hline
\end{tabular}

nights working as translators. It is a demanding role and is certainly not a holiday!

The IESO competition consists of two parts: a written examination and a practical examination. The written examination aims to examine the participating students' understanding of the theoretical knowledge of Earth science (Fig.1F). The practical examination (Fig. 1B, D, E, G) includes experiments and field tasks designed to evaluate the students' capacity for conducting experiments or solving problems in the field of Earth science.

The IESO examinations are prepared by specialists in Earth science and/or Earth science education, who also provide solutions and evaluation guidelines. Participants are given the theoretical problems and experimental or field tasks in a written format and supplied with materials required to solve the problems and conduct the experiments.

In addition to the contest activities, related activities such as the International Team Field Investigation (ITFI) are organized in order to promote cooperation between team members from different cultural backgrounds (Fig.1C). The ITFI activity regroups participating students into teams that are not based on their home country to conduct field investigations and to perform group presentations later in the Olympiad. These are conducted in front of the ITFI judges and all the IESO participants. Finally, the outstanding student teams are awarded with the certificates for "Best Cooperation Team", "Best Team: Creativity" and "Best Team: Presentation". Other science Olympiads do not have field activities so the ITFI is unique to the IESO and creates a different dynamic for the participants.

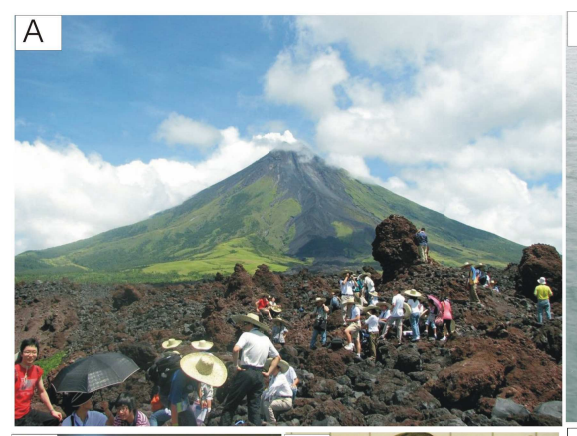

experts, cultural trips (Fig.1A), and visits to local schools. The diversity of overseas visitors the event brings to the host city attracts the local media and public authorities.

The IESO is usually held in September/October and the participants are selected in the same year or sometimes in the previous school year depending on each participating country. The local organizing committee invites all countries that are accepted as members of the competition. The organizer must provide all participating countries with a schedule of the activities during the competition and prepare a final report at the conclusion of the event.

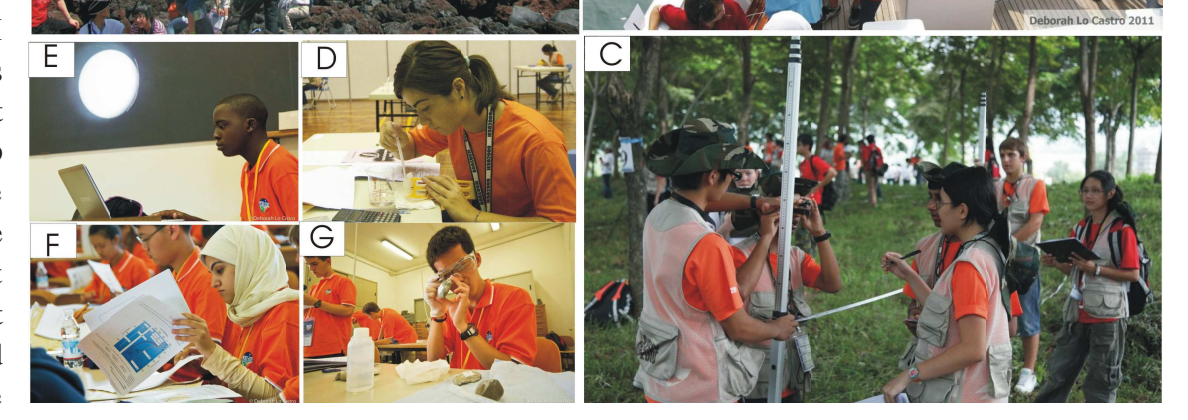

Figure 1. (A) Field trip, IESO 2008, Philippines. (B) Hydrosphere practical test in Venice lagoon in 2011 (by Deborah Lo Castro). (C) International Team Field Investigation ITFI, Taiwan 2009 (Lee Che-Di). (D) Atmosphere practical test, Taiwan 2009 (by Chung Chu-Hsiang). (E) Astronomy practical test, Italy, IESO 2011 (by Deborah Lo Castro). (F) Written test (by Deborah Lo Castro). (G) Geology practical test (by Deborah Lo Castro) IESO include plenary sessions with scientific 


\section{A brief history of IESO}

Prior to 2003, the idea of the International Earth Science Olympiad (IESO) was suggested by several Korean Earth Scientists. In 2003, the Korean Earth Science Society organized the first Korean Earth Science Olympiad (KESO), followed by the second (2004) and the third (2005). Following this initial positive experience, in 2003 the concept of an IESO was put to the IGEO Council members at the International IGEO Council meeting which was part of the Fourth International Conference on Geoscience Education (GeoScieEd IV) held in Calgary, Canada. The Council established that the International Earth Science Olympiad would become one of the main activities of the IGEO with a 10 member IESO Committee (Chairperson: ChanJong Kim, Korea) established.

In 2004, during the management team meeting for the $32^{\text {nd }}$ IGC in Florence, Italy, Eduardo de Mulder and Ted Nield of the International Year of Planet Earth (IYPE) agreed to support IESO as one of the activities of the IYPE. In November 2004, an IESO Conference was held in Seoul (South Korea) with representatives from ten countries. The aim was to discuss the Earth Science curricula and a desirable format of the IESO. There were 23 presentations and the IESO Coordinating Committee was established. It was composed of 11 members including the chairperson, Prof. Moo Young Song. The IESO Committee was renamed the IESO Advisory Committee and the statutes for the IESO were also finalized.

During the first meeting of the IESO Coordinating Committee, held during the Seoul Conference, it was concluded that Korea offered the best conditions and the most favourable atmosphere for hosting the first IESO. The efforts of the Committee combined with a great personal contribution of Prof. Moo Young Song resulted in the first
International Earth Science Olympiad taking place in Korea in 2007 (Greco, 2012a) (Fig.2).

In 2005 the IESO Syllabus Commission (Chairperson: Nir Orion) was established and the first draft of the IESO Syllabus was elaborated (http://ieso2008.org/history.php). The IESO logo was designed and approved by the IESO Advisory Committee in March 2006.

The IESO is hosted by a different country every year and the organizing committee from the host country choses the theme for the competition:

- 2007 - 1st edition - Republic of Korea, theme: Earth for Life, Universe for future Life

- 2008 - 2nd edition - Philippine, theme: Cooperation in Addressing Climate Changes

- 2009 - 3rd edition - Taiwan, theme: Human and Environment

- 2010 - 4th edition - Indonesia, theme: The Present is the Key to the Future

- 2011 - 5th edition - Italy, theme: Earth Science Renaissance: Science, Environment and Art

- 2012 - 6th edition - Argentina, theme: Energy, water and minerals for sustainable development

- 2013 - 7th edition - India, theme: The Earth is indeed a family

- 2014 - 8th edition - USA

- 2015 - 9th edition - Russia

- 2016 - 10th edition - Japan

Until 2010, the IESO had only been held in Asia and the next two editions were also planned to be held in this region. This pattern ran the risk of the IESO being called an Asian Olympiad. By 2010, 22 countries had taken part in the IESO at least once. Among these 16 countries are located in Asia. The primary reason for this situation
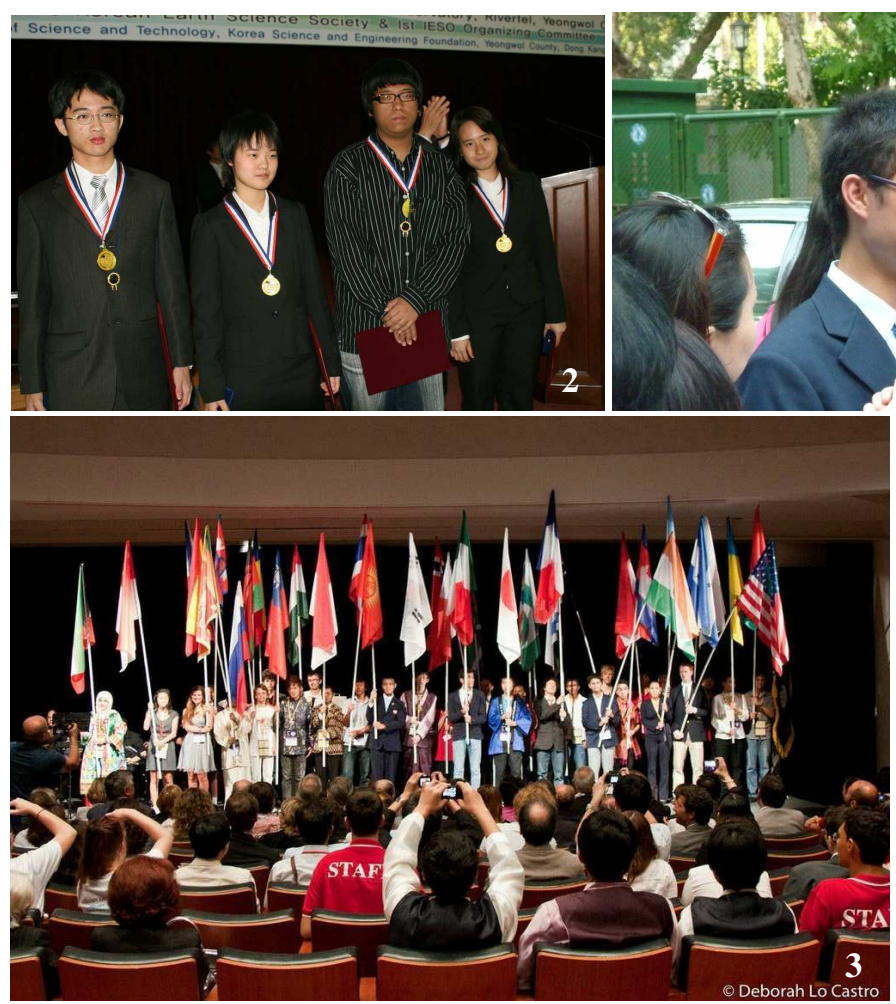
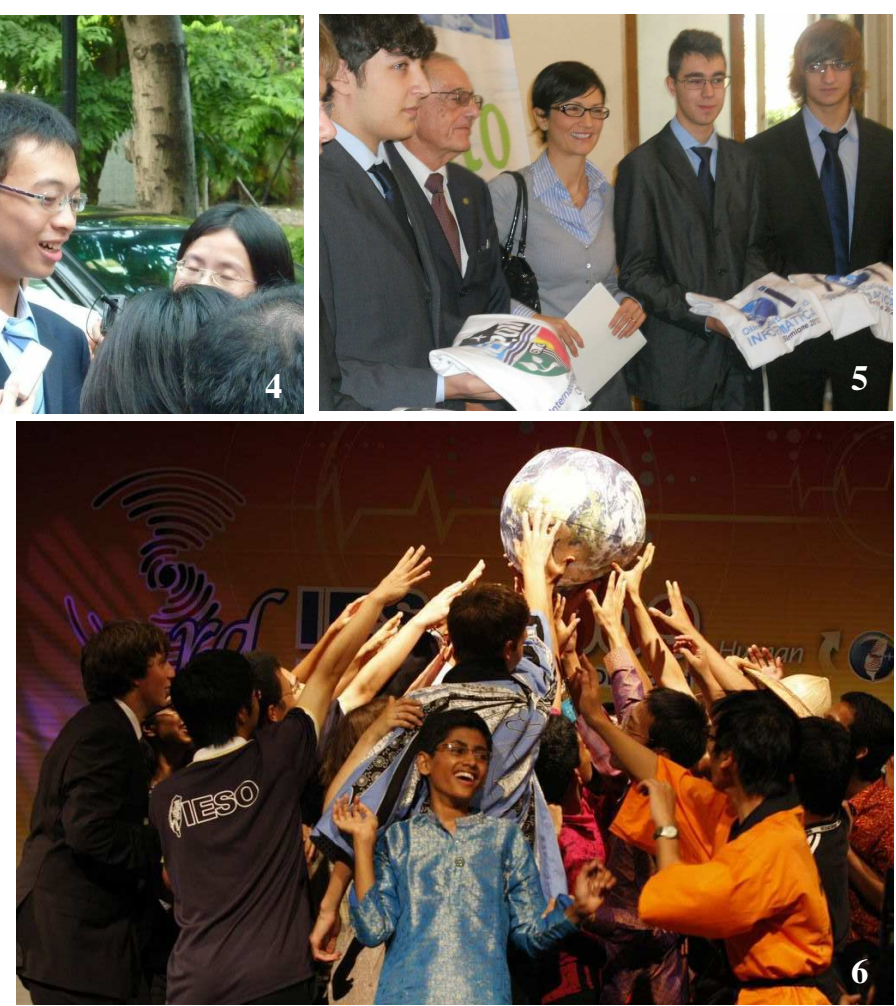

Figure 2 First gold medals from IESO 2007, Korea. Figure 3 Opening ceremony IESO 2011 (by Deborah Lo Castro). Figure 4 Best student of IESO 2009 interview by media (Ebony Ding). Figure 5 Italian students team of IESO 2010 meet the Minister of Education, in the centre of the pictures (by Fedor Getman). Figure 6 Farewell party, Taiwan 2009 (by Huang Sheng-Ting). 
was that it was not always easy to involve non-Asian countries in the organization of the IESO. Italy was the first European country to take part in an IESO sending a full team in 2009. In 2011, Italy managed to host the $5^{\text {th }}$ edition, bringing the event to Europe.

The $6^{\text {th }}$ edition in 2012 was supposed to be hosted by Japan but due to the terrible tsunami that followed the earthquake off the Pacific coast of Tôhoku on April 7, 2011, causing power shortages and a nuclear hazard, the Japanese organisers resigned from holding the IESO. Calls were put out to other participating countries to host the event, with Argentina courageously arranging the 2012 edition in only 18 months and with extremely limited resources.

From 2007 to 2012, 39 countries have taken part in at least one IESO edition with 353 students involved in the competition. The countries that have participated at least once with student teams are: Australia, Belarus, Brazil, Cambodia, France, Germany, Honduras, Hungary, India, Indonesia, Israel, Italy, Japan, South Korea, Kuwait, Kyrgyzstan, Malawi, Maldives, Mongolia, Nepal, Philippines, Romania, Russia, Singapore, Spain, Sri Lanka, Taiwan, Thailand, Ukraine, United Kingdom and USA. The countries that have participated at least once with observers are: Argentina, Austria, Cyprus, Malaysia, Malta, Norway, Pakistan and South Africa (Fig.3).

Some countries have become regular participants while others, especially from developing countries, have been able to implement an in-country Earth Science Olympiad competition from which a national team could be selected, but participation in the IESO is difficult to support due to the high cost of the travel and a lack of sponsorship. This is of real concern, particularly for many African countries where there is even more urgent need to educate new generations in Earth science in order to have geoscientists and geotechnicians able to search for and sustainably develop the rich Earth resources of the African continent (Martínez-Frías, Mogessi, 2012). Here it is even more important to teach young people the long term consequences of human activities on the Earth system, such as contamination of soil and water by quarry and mining activities, waste management and climate change.

\section{Organization of IESO}

The IESO is organized by international bodies as follows:

The Advisory Board of the IESO advises the Coordinating Committee and ensures the high standards of the IESO are maintained. The Advisory Board is chaired by the chairperson of IGEO. The Advisory Board consists of International Council members of IGEO and representatives of related international organizations who are assigned by the chairperson as members of the Advisory Board.

The Coordinating Committee attends to the long-term work involved in organizing the IESO. The members of the Coordinating Committee are the chairperson of IGEO and representatives of the countries which have hosted the IESO during the past two years and the countries which will host the IESO in the next two years. The Coordinating Committee elects its own chairperson and completes its work in collaboration with the chairperson and the organizer of the IESO in accordance with the aims and regulations of the IESO.

The International Jury is an ad hoc body formed for each competition. The International Jury consists of the chairperson and up to two representatives each from all delegations. It is chaired by a distinguished specialist in earth science and/or earth science education who is appointed by the organizing country of the IESO.

In addition the country that host the IESO create a Local
Organizing Committee that takes care to arrange all the logistic related to the event and the Local Scientific Committee that has the duties to prepare the scientific test (Statutes of the International Earth Science Olympiad, 2007).

\section{Aims of the IESO}

The aims of the IESO are primarily to raise student interest in Earth science thus to reach the wider population, first through the students family and then the broader community. Student participation in country team selection processes has the potential to identify talented and gifted students in Earth science and motivate them to follow a geoscience career (Fig. 4). The IESO also aims to encourage friendly relationships among young learners from different countries and promote international cooperation. Through social media it is easy for past participants to keep in touch with friends from across participating countries.

Another aim of the IESO is to improve Earth science teaching in schools globally. It provides an important professional development opportunity for the mentors, who are experts in Earth science education to meet colleagues from other countries and have the opportunity to exchange ideas and materials about Earth science and Earth science education.

\section{Impact at national level}

The International Earth Science Olympiad has the potential to influence the quality of countries' Earth science curriculum especially if a country conducts a national Earth Science Olympiad. A national program and selection process that enables students from around a country to participate is likely to attract the attention of the mass media and educators.

An example of how a country may conduct a national competition can be seen in Italy. In Italy Earth science is a subject compulsory for all students in secondary school. The exact number of hours per week allocated to Earth science and whether it is taught as a separate subject or within a broader natural science framework is dependent on the school type.

The selection for IESO is done by the Italian Natural Science Teachers' Association (Associazione Nazionale Insegnanti di Scienze Naturali - ANISN). All schools with a secondary enrolment receive the information and the students of the school that decide to participate have the opportunity to participate in the national selection. In 2011, when Italy was the IESO host country, 443 schools participated in the national selection process. Each school selected the best 4 students to participate in an event at the regional level. On the same day, a multiples choice test was administered to the students in 20 regions across Italy. The best 10 students from this test then went on to the next level of the national selection process involving a week of preparation in a university. Four best students from this were then finally selected to take part in the IESO. These four students were selected from approximately 25,000 students that took the national selection test (Greco, 2009). This is evidence of a strong competition for just 4 places in the final national team, and a strong interest in Earth science among Italian secondary school students.

Since 2010, the Italian IESO team preparation has taken place in the Earth Science Department of the University of Study, Camerino. The university professors conducting the training program were surprised by the level of interest, attention and motivation of 15-16 
years old students. During the training program several university professor provide lectures on topics from the IESO syllabus. Part of the training is dedicated to the students working through the previous IESO editions tests in groups then clarifying the answers with the professors. In addition, field trips are organized in order to improve field skills the students require for the International Team Field Investigation component of the IESO, and the students have the opportunity to visit the laboratory of the department.

Italy, like most countries, has experienced a drop in the numbers of freshmen wishing to study Earth Science at the University level. This trend began in the 2003/2004 academic year, where the numbers went from 1519 to 1052 in 2009/2010, an average decrease of 5\% per year. In 2010/2011 the number showed an increase to 1351 ; but dropped slightly in 2011/2012 to 1334 .

The number of freshman in the Geology course offered at Modena and Reggio Emilia University, which was the host for the IESO in 2011, has increased from 19 in 2009/2010 to 32 in 2011/2012. The number of natural science freshman students (studying a semester of geology) at Modena University has also increased from 22 in 2009/ 2010 to 50 in 2011/2012 (http://anagrafe.miur.it/index.php) (Greco \& Gualtieri, 2010).

The Italian Ministry of Education decided to support the national selection process and the organization of IESO 2011. The 4 students and one of the mentors that participated at IESO 2010 met with the Minister of Education in 2010 (Fig.5). The team was able to describe to the Minister the impact of participating in the IESO and outline plans about how they would conduct IESO 2011 in Italy. They could show that the IESO was an effective way to promote Earth science education and career paths into related fields across Italy. University Earth science academics also became interested in supporting Italy to host the IESO in 2011 and could see how they could be active contributors to the activities of the IESO.

In Spain, the team selection is carried out by the Asociación Española para la Enseñanza de las Ciencias de la Tierra (AEPECT, the Spanish Associations for teaching Earth Sciences). In 2010, AEPECT started the selection process for the first Spanish team to compete in the $5^{\text {th }}$ IESO in 2011. The selection for the 2011 team was held in 20 locations across Spain with the winner of each local selection participating at the national selection level. The results of a survey that these students undertook indicated that the selection process was a worthwhile experience for them and many students commented they would like to participate in the next selection (Calonge and Greco, 2011).

\section{Conclusion}

Humanity is facing new challenges concerning the need to manage the environmental impact of increased extraction of Earth resources to meet the needs of a rapidly growing population. A strong curriculum in Earth science is necessary to enable the next generation to address continuing and new environmental challenges. The IESO provides a good mix of science, competition, cooperation and fun and is a tool to grow interest in Earth science in school students, teachers and the general public in a range of countries. There is considerable evidence that the media in countries that host the IESO and that have National competitions are keen to cover these events (http://www.ieso2011. unimore.it; Greco, 2012b). The event is also an effective way to apply pressure the minister of education to strengthen the Earth science component in schools' curriculum.
The International Geographical Congress offers an interesting idea that maybe could be taken up in the future by the International Geological Congress. The International Geographic Olympiad is held in the same location as the International Geographical Congress, beginning a few days before, with the gold medals awarded during the opening ceremony of the congress. While this arrangement would only coincide with the IESO every fourth year, it would provide an effective way to link the activities of the Congress with that of the Olympiad and the school sector.

The number of countries that participated to IESO is still low probably due to the fact that it is a recent Olympiad and even that Earth Science is a weak or missing subject in several countries (King, 2008). The national selection process is usually managed by teachers associations and Ministries of Education. The Geological community, both academic and professional could play an important role to promote this activity at national level.

We feel that Episodes is the perfect place to call upon all interested in Earth Science Education to become involved in the IESO by making contact with the IESO organisers listed below or via the main IESO website and register interest. Participation as a guest or observer is encouraged. Observers from past events have reported fond memories they have of the event and the motivation to begin the process of developing a national event and selection process in their home country .

The 7th IESO was hosted by India and held in Mysore from 1119 September 2013: http://www.ieso2013.in; Prof. R. Shankar can be contacted for details of the event (E: rshankar_l@yahoo.com)

Contacts for next IESO

8th IESO 2014, USA: www.YouthKnOWS-Aquacy.com, contact: tbtailer@hotmail.com

9th IESO 2015, Russia, contact: geology @ herzen.spb.ru

$10^{\text {th }}$ IESO 2016, Japan, contact: esolympiad2@geol.tsukuba.ac.jp

Main IESO website: http://www.ieso-info.org/

\section{References}

Calonge García, A., Greco, R., 2011, Olimpiada Internacional de Ciencias de la Tierra (IESO): Una oportunidad a la Geología. Enseñanza de las Ciencias de la Tierra, 19(2): 130-140.

Greco, R., 2009, International Earth Science Olympiad - IESO 2009, Taiwan 14-22 Settembre 2009, Geoitalia N`29. Livorno, pp 22-30.

Greco, R., Gualtieri, A. F. (2010) Studio Geologia perché... Risultati preliminari sull'indagine quali-quantitativa relativa alla scelta del corso di laurea in Scienze Geologiche Geoitalia n ${ }^{\circ} 30$ Livorno, pp.38-41

Greco, R., 2012a, IESO 2011 Final report, Centro Stampa UniMoRE, Modena, pp 252.

Greco, R., 2012b, International Earth Science Olympiad - IESO 2011, Earth Science Renaissance, Science, Environment and Art, Modena 5-14 settembre 2011. Geoitalia n 37 Livorno, pp. 14-32.

King, C., 2008, Geoscience Education: an overview. Studies in Science Education, 44, 187 - 222.

Martínez-Frías J., Mogessie A., 2012, The need for a geoscience education roadmap for Africa, Episodes, Vol. 35, no.4, 489-492.

Statutes of the International Earth Science Olympiad, 2007 http://www.iesoinfo.org/

Verhoeff T., Horv'ath Gy., Diks K. and Cormack G., 2006, A proposal for an IOI Syllabus, Teaching Mathematics and Computer Science, 4/1, 193216. 